\title{
FEATURES OF MODELING IMAGES OF INTERVIEWER AND INTERVIEWER IN PRINTED MEDIA
}

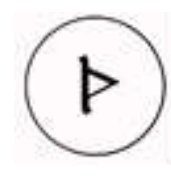

\author{
Hanna Kholod, \\ PhD in Philology, Chief Executive Officer \\ E-mail:kholodanna@ukr.net, \\ https://orcid.org/0000-0002-2479-9721, \\ ResearcherID: AAD-5685-2020, \\ $N G O$ "Scientific and Educational Center \\ «SUCCESSFUL», \\ Gnat Yura st., 3, of. 44, Kyiv, \\ Ukraine, 03148.
}

\section{Citation:}

Kholod, H. (2021). Features of Modeling Images of Interviewer and Interviewer in Printed Media. Social Communications: Theory and Practice, Vol. 12(1), 49-62. DOI: $10.51423 / 2524-0471-2021-12-1-11$

Retrieved from https://new.comteka.com.ua/index.php/journal/articl e/view/105

(C) Kholod H., 2021

(c) EY

Attribution 4.0 International (CC BY 4.0)

\section{ANNOTATION}

The aim of the research in the article was to clarify the features of modeling the images of the interviewer and the interviewee in print media. The study allowed expanding the theoretical basis in the study of interviews, filling in some gaps and outlining discussion points. The author's vision of the specifics of modeling the images of the interviewer and the interviewee in print media is proposed. A three-stage mechanism for modeling the images of the interviewer and the interviewee is presented. The specificity of the emergence and functioning of the communicative manipulative field between the participants of communication has been determined. A list of communicative manipulative techniques that can be activated when a manipulative field appears.

Methods of description, analysis, synthesis and generalization were used. The following research procedure has become the methodology: 1) among the theoretical material, scientific works related to the topic we are going to have been selected; 2) scientific articles, monographs are analyzed, 3) controversial statements are highlighted in them and the author's point of view regarding the subject of research is presented; 4) the author's concept of modeling the image of the interviewer and the interviewee is proposed.

The results and discussion made it possible to formulate conclusions. Firstly, the images of the interviewer and the interviewee go through the following stages of modeling: the formation of the aforementioned images during the communicative process, the transformation of the images of the interviewer and the interviewee while working on a journalistic text, modeling in the mind of the recipient the images of the interviewer and the interviewee, determined by the specifics of the perception and interpretation of the proposed information by the representative. media audience. Secondly, the images of the interviewer and the interviewee are multivariate. The factors of multivariate are the purpose of the interview, the communicative situation, the participants in communication, their worldview orientations, discourse, epistemic characteristics of the participants in communication, the transformation of images due to the work process and the specifics of perception, as well as the interpretation of information by the media audience.

Key words: interviewee, interviewer, media audience, modeling. 


\title{
ОСОБЛИВОСТІ МОДЕЛЮВАННЯ ОБРАЗІВ ІНТЕРВ’ЮЕРА Й ІНТЕРВ'ЮЙОВАНОГО В ДРУКОВАНИХ ЗМІ
}

\author{
Ганна Холод, \\ кандидат філологічних наук, \\ директор ГО \\ "Науково-освітній иентр "УСПІШНИЙ”
}

\section{Вступ}

Журналістикознавці, які досліджують інтерв’ю, приділяють увагу вивченню портретного інтерв'ю (Френкель, 2014), “ролі каналів зв'язку з метою встановлення контакту між адресантом і адресатом як партнерами комунікації” (Кузьменко, 2015: 58), модифікацій інтерв'ю (Сазонова, 2013), прагмалінгвістичного аспекту інтерв'ю (Штирьова, 2006), функцій інтерв'ю, його мети й завдань (Долгіна, Весніна, 2015), видів інтерв'ю (Шарапов, 2017) тощо. Дослідженню інтерв'ю як жанру журналістики присвятили свої праці й Natsvlishvili P. (Natsvlishvili, 2013); Kazimova J. (Kazimova, 2018); Kovtunenko, I., Bylkova, S., Borisenko, V., Minakova, N., Rogacheva, V. (Kovtunenko, Bylkova, Borisenko, Minakova, \& Rogacheva, 2018); Melo, J. M. de, Assis, F. de (Melo, Assis, 2016). Обрана нами тема була побіжно згадана журналістикознавцями й, на нашу думку, потребує детального вивчення. Це не лише дозволить розширити теоретичну базу щодо інтерв'ю, заповнивши деякі прогалини, a й, окресливши дискусійні моменти, запропонувати власне бачення щодо специфіки моделювання образів інтерв'юера й інтерв'юйованого в друкованих ЗМІ. Зокрема, плануємо презентувати трьохетапний механізм моделювання образів інтерв'юера й інтерв'юйованого; окреслити специфіку виникнення й функціонування комунікативного маніпулятивного поля між учасниками комунікації, запропонувавши комунікативну модель-тріаду (IIM інтерв'юер - інтерв'юйований - медіаудиторія); сформулювати перелік комунікативних маніпулятивних прийомів, що можуть активізуватися під час появи маніпулятивного поля; запропонувати форми активної авторизації; доповнити засоби моделювання образів інтерв'юерів й інтерв'юйованих; обгрунтувати необхідність введення епістемної характеристики учасників комунікації.

Мета - з'ясувати особливості моделювання образів інтерв'юера й інтерв'юйованого в друкованих 3МІ.

Об’єкт дослідження - образи інтерв'юера й інтерв'юйованого в друкованих ЗМІ.

Предмет дослідження - особливості моделювання образів інтерв'юера й інтерв’юйованого в друкованих 3МI.

\section{Методи та методика дослідження}

Для досягнення поставленої мети було використано такі методи: описовий, аналіз, синтез, узагальнення.

Виконано таку дослідницьку процедуру:

1.Серед теоретичного матеріалу обрано наукові роботи, дотичні до обраної нами теми. 
2.Проаналізовано наукові статті, монографії тощо.

3. Виокремлено в них дискусійні твердження й викладено свою точку зору щодо предмета дослідження.

4.Запропоновано свою концепцію моделювання образу інтерв'юера й інтерв'юйованого.

\section{Результати й обговорення}

Перш ніж висвітлювати запропоновану нами тему, треба окреслити різницю між автором художнього тексту й автором публіцистичного тексту. Слушною щодо цього теоретичного питання є думка дослідниці С. Распопової, яку вона вербалізувала в статті “Автор як реальна людина та образ автора в медіатексті” (Распопова, 2015). Зокрема, С. Распопова зазначила, що, на відміну від автора художнього твору, автор публіцистичного тексту "є складною конструкцією, що містить суспільне (соціальне) та особисте, тобто індивідуальні світоглядні, психічні особливості та нахили” (Распопова, 2015: 152), і наголосила на такій детермінанті творчості журналіста як медіаудиторія. Вищезазначене також дає можливість стверджувати, що $є$ різниця між автором-реальною людиною й образом автора в медіатексті, що під впливом багатьох чинників зазнає процесу трансформації.

У статті Р. Урунової "Про способи авторизації сучасного газетного тексту" констатувала тенденцію щодо активізації “авторизації публіцистичного дискурсу” (Урунова, 2015: 264), звернула увагу на залежність ступеня авторизації від жанру журналістського тексту, проаналізувала типові й найчастотніші авторизації медіатексту, окресливши перспективу їхнього подальшого вивчення. Зокрема, акцент було зроблено на метатекстових включеннях, які, на іiі думку, “є роздумами автора про створену ним картину дійсності, аналіз його психічного стану, пояснення мотивів звернення до цієї теми” (Урунова, 2015: 264).

Участь реципієнтів у моделюванні образів інтерв'юйованого й інтерв'юера окреслила О. Френкель, лише згадавши про "аналіз аудиторією отриманої інформації і, таким чином, створення конкретного образу як журналіста, так і респондента" (Френкель, 2014: 31). Ю. Бикова в статті “Образ журналіста: еволюція сприйняття в новійший час”, зазначаючи втрату довіри медіаудиторії до діяльності журналіста, констатує негативну тенденцію щодо появи його “симптому “розколотого образу” (Бикова, 2009: 7), сутність якого полягає у виявленні під час соціологічних досліджень діаметрально протилежного ставлення до журналістів у представників медіаудиторії. У своїй статті приділимо увагу реципієнтам як представникам медіаудиторії, які беруть активну участь у моделюванні образів інтерв'юйованого й інтерв'юера.

О. Кузьменко, констатуючи у своїй статті “Особливості комунікативної ситуації інтерв”ю та ії складників” (Кузьменко, 2015) “величезний вплив на аудиторію” (Кузьменко, 2015: 60) інтерв’ю, стверджує наявність у ньому “маніпулятивних стратегій і тактик відносно респондента (що проявляється у відборі інтерв’юером питань і диригуванні ходом розмови) чи відносно вторинного адресата - аудиторії читачів чи слухачів (що проявляється у зміні уже сформованих позитивних/негативних установок стосовно опитуваного на кардинально протилежні або відході від нейтрального ставлення до інтерв'юйованого)" (Кузьменко, 2015: 60). На нашу думку, з огляду на вищезазначене дослідницею не було враховано аспект 
партнерства між учасниками комунікації, що передбачає наявність взаємної маніпуляції під час інтерв'ю. Помилковою, на наш погляд, є думка про те, що медіаудиторія є лише об'єктом маніпуляції, адже іiї інтереси детермінують вибір інтерв'юйованого, мету інтерв'ю, його тематичні вузли тощо. Уже у своїй дисертації вищезазначена дослідниця "Презентація респондента в анлійськомовному інтерв”ю масмедійного дискурсу: лінгвокомунікативний i лінгвокогнітивний виміри” (Кузьменко, 2019) негативно конотує маніпуляцію, відносячи маніпулятивну тактику до “тактики негативного представлення респондента" (Кузьменко, 2019: 265), із чим ми не згодні, оскільки в нас є свою точка зору щодо поняття "маніпуляція", яку викладемо під час аналізу визначення С. Сербина: “маніпуляції в інтерв'ю - це прихований вплив інтерв'юера на інтерв'юі для досягнення власних цілей, зворотність яких може проявлятися як у будь-якій фізичній формі, так і відображатися на емоційному рівні його учасників" (Сербин, 2015: 39). 3 огляду на вищезазначене хочемо зробити декілька зауважень.

1.Досліджуючи маніпуляції (інтерв'юер - інтерв'юйований) в інтерв'ю, не можна ігнорувати важливу складову, що впливає на вищезгаданий комунікативний процес медіааудиторію, на яку орієнтується інтерв'юер й інтерв'юйований (співавтори), створюючи інформаційний продукт й ураховуючи її інформаційні потреби й інтереси. Зокрема, ідеться про узагальнений образ реципієнта, його соціально-психологічний портрет, який моделюється в уявленні інтерв'юера й інтерв'юйованого, детермінує їхню комунікативну поведінку. На нашу думку, під час інтерв'ю учасники цього комунікативного процесу опиняються в маніпулятивному колі, постійно перетворюючись із суб'єкта маніпуляції на іï об'єкт.

2.Вважаємо, що з огляду на маніпуляцію як невід’ємну складову комунікаційного процесу, яка має постійний експліцитний і потенційний імпліцитний вияв вищезгадане визначення маніпуляції під час інтерв'ю недоречно обмежувати тільки прихованим впливом і трактувати його як однобічний процес (лише інтерв'юер впливає на інтерв'юйованого). На нашу думку, варто звернути увагу на визначення терміна “маніпуляція", запропонованого Б. Мещеряковим, В. Зінченко й позбавленого негативних конотацій: “комунікативний вплив, який актуалізує в об'єкта впливу певні мотиваційні стани (одночасно й почуття, атитюди, стереотипи), що спонукають його до поведінки, яка бажана (вигідна) для суб'єкта впливу; при цьому не передбачається, що вона обов'язково повинна бути невигідна для об'єкта впливу" (Большой психологический словарь, 2009: 245), й уточнити декілька моментів.

1.Під час спілкування відбувається взаємовплив, тобто суб'єкт впливу стає об'єктом впливу й навпаки. Як зазначали вище, між учасниками комунікації автоматично виникає маніпулятивне коло, взаємовплив у якому підсилюється тоді, коли учасники комунікації намагаються реалізувати свої інтенції стосовно один одного. 3 огляду на вищезазначене під час інтерв'ю між інтерв'юером та інтерв'юйованим виникає взаємовплив, ступінь якого зумовлений їхніми інтенціями, ефективністю їх реалізації під час вищезгаданого комунікативного процесу й адекватністю кодування та декодування експліцитних та імпліцитних смислів, створених за допомогою вербальних і невербальних засобів. Ступінь адекватності кодування і декодування залежить від соціокультурного середовища учасників комунікації, а також їхніх психічних процесів, властивостей, психічних станів, що можуть бути детерміновані гендерними особливостями інтерв'юера та інтерв'юйованого. За умови полярності (максимальний вияв відмінностей) вищезазначених чинників кодування та декодування експліцитних та імпліцитних смислів може відбутися суттєве викривлення 
інформації, що під час іï сприйняття призводить до оказіональної (випадкової, незапланованої) появи вірулентних (патогенних) смислів, здатних спричинити інтоксикацію комунікації. Під час інтерв'ю інтерв'юер повинен уміти, вчасно помітивши виникнення вірулентних смислів, нейтралізувати їх. Крім вищезазначеного, під час комунікації варто враховувати специфіку різновидів імпліцитного змісту: “текстовий” (Бацевич, 2004: 157) (“інформація, яка відповідає явним комунікативним намірам адресанта" (Бацевич, 2004: 157), “підтекстовий” (Бацевич, 2004: 158) (“інформація передавання якої входить у приховані комунікативні наміри відправника тексту (адресанта, мовця, автора)” (Бацевич, 2004: 158), “притекстовий” (Бацевич, 2004: 158) (“інформація, яка може бути виведена $з$ тексту, хоча ії передавання і не входило в комунікативні наміри адресанта" (Бацевич, 2004: 158), виникнення яких зумовлено особливостями продукування, сприйняття, інтерпретації інформації учасниками комунікації.

Нагадаємо, що експліцитні та імпліцитні смисли, виникаючи між інтерв'юером та інтерв'юйованим завдяки вербальним та невербальним засобам, створюють первинний текст, що має декілька етапів трансформації: під час розшифровки інтерв’ю й очищення його від нечитабельних елементів (слів-паразитів, тавтології, від граматично неправильно сформульованих речень тощо), під час редакторських правок, під час узгодження тексту 3 інтерв'юйованим й отримання від нього дозволу на друк. Вищезгаданим етапам трансформації первинного тексту притаманне викривлення образу інтерв’юера й образу інтерв'юйованого.

Трансформований текст $є$ викривленим інформаційним продуктом, оскільки він не тільки може бути позбавлений інформації щодо використання невербальних засобів комунікації, а й містить вербальні засоби, що стали об’єктом коригування, зумовленого необхідністю дотримуватися мовних норм, чинного законодавства України, етичного кодексу журналіста. Стаючи об’єктом сприйняття медіааудиторії, трансформований текст проходить подальшу трансформацію. Під час неї відбувається продукування експліцитних та імпліцитних смислів, варіативність і ступінь викривленості яких залежить від психічних процесів, психічних станів представників медіааудиторії, дискурсу, епістеміологічної характеристики медіааудиторії, інтерв'юера та інтерв'юйованого, яка важлива для усвідомлення причин виникнення комунікативних бар'єрів між продуцентом (інтерв'юер, інтерв'юйований, медіааудиторія) та реципіснтом (інтерв'юер, інтерв'юйований, медіааудиторія). Їх позиції під час інтерв'ю $є$ динамічними (продуцент стає реципієнтом, реципієнт - продуцентом) і можуть бути представлені схемою: інтерв'юер, ураховуючи комунікативні інтереси медіаудиторії та специфіку інформації про інтерв'юйованого, продукує інформацію, яку сприймає, інтерпретує інтерв'юйований, продукуючи експліцитні та імпліцитні смисли. Їх сприймає та інтерпретує інтерв'юер, продукуючи експліцитні та імпліцитні смисли; трансформований інформаційний продукт сприймає, інтерпретує медіааудиторія, продукуючи експліцитні та імпліцитні смисли не тільки під час поступового ознайомлення 3 інформаційним продуктом, а й після отримання цілісного уявлення про нього. На відміну від інтерв'юера та інтерв'юйованого, медіааудиторія продукує інформацію, яка має експліцитний вияв за умови вербалізації думки у формі коментаря, репліки тощо.

Введення терміна “епістемна характеристика” інтерв'юера (продуцента-реципієнта) й інтерв'юйованого (реципієнта-продуцента), представника медіаудиторії (реципієнтапродуцента) зумовлена радикальною зміною ідеологічного вектора розвитку суспільства 
конкретної країни. На відміну від процесів консонантивної епістемної дифузії, притаманних країнам, у яких не відбулося різкої ідеологічної деструкції, у країнах колишнього Радянського Союзу, зокрема в Україні, після його розпаду виник епістемний дисонанс, репрезентований наявністю контраверсійних епістем (епістема Радянського Союзу епістема незалежної України), що зумовив виникнення таких реакцій на вищезгаданий процес:

1.Прийняття нової епістеми й заперечення старої.

2.Неприйняття нової епістеми, ідеалізація старої.

3.Епістемна адаптація (часткове прийняття нової епістеми без повного заперечення старої).

Кожному вищезгаданому процесові відповідає епістемна характеристика (епістемноноваційний, епістемно-консервативний, епістемно-адаптивний) учасників комунікативного процесу, які у форматі тріади (інтерв'юер, інтерв'юйований, медіаудиторія), притаманної інтерв'ю, одночасно є продуцентами та реципієнтами інформації.

Пропонуючи введення терміна “епістемна характеристика", ми орієнтувалися на таке визначення епістеми: “структура, що суттєво обумовила можливість визначення поглядів, концепцій, наукових теорій і власне наук у той чи інший історичний період” (Что такое эпистема, 2021).

2. Вважаємо, що позитивно конотована маніпуляція, якій не притаманний процес віктимізації, тобто перетворення учасника комунікації на жертву в результаті психологічного впливу продуцента інформації, є невід’ємною частиною паритетної комунікації, під час якої зберігається рівноправність учасників комунікації. Негативної конотації маніпуляція набуває тоді, коли в результаті цілеспрямованого експліцитного та / або імпліцитного впливу активізується процес віктимізації учасника комунікації. Варто, на нашу думку, говорити про можливість виникнення ілюзорної негативно конотованої маніпуляції, яка є результатом викривленої інтерпретації, що відбувається в результаті неправильного декодування отриманої інформації, детермінованого наявністю в одного 3 учасників комунікації віктимних нахилів. Допускаючи потенційну можливість виникнення ілюзорної маніпуляції, яка не є обов'язковою для комунікативного процесу, зосереджуємо увагу на таких видах маніпуляції, як експліцитна та імпліцитна, і пропонуємо класифікацію їх комунікативних прийомів, які можуть бути використані під час інтерв’ю.

На нашу думку, експлічитна маніпуляція, диференціація якої на позитивну, негативну, збалансовану відбувається залежно від конструктивної (моделювання позитивного образу учасника комунікації, пошуки виходу з проблемної ситуації), деструктивної (моделювання негативного образу учасника комунікації, увиразнення негативних наслідків проблемної ситуації) мети впливу на учасника комунікації, а також інтенції об'єктивно висвітлити інформацію, має такі комунікативні прийоми:

1) переконування, тобто використання аргументів для зміни рішення, думки, ставлення учасника комунікації;

2) прохання задовольнити бажання учасника комунікації;

3) ігнорування. Навмисно не помічати деякі особливості комунікативної поведінки учасника комунікації, зокрема вербальні та невербальні засоби комунікації;

4) конструктивна критика учасника комунікації, третіх осіб, конструктивна самокритика одного з учасників комунікації; 
5) деструктивна критика учасника комунікації, третіх осіб, деструктивна самокритика одного з учасників комунікації;

6) формування в одного учасника комунікації позитивного ставлення до ситуації, явища, третіх осіб, іншого учасника комунікації;

7) формування в одного учасника комунікації негативного ставлення до ситуації, явища, третіх осіб, іншого учасника комунікації;

8) переривання думки учасника комунікації;

9) демонстрування незгоди в думках, озвучення опозиційної точки зору;

10) пропозиція проаналізувати когнітивно-дисонансні приклади;

11) пряме схвалення думок і вчинків учасника комунікації, третіх осіб (близьких, знайомих, опонентів тощо);

12) пряме засудження думок і вчинків учасника комунікації, третіх осіб (близьких, знайомих, опонентів тощо);

13) пряме самовихваляння;

14) неправильна інтерпретація інформації;

15) стимулювання. Зацікавленість журналіста конкретною інформацією зумовлює появу стимулу в інтерв'юйованого розповісти більше;

16) деталізація почутого. З’ясування деталей інформації 3 метою активізації інтерв’юйованого щодо більшої інформації;

17) перевірка правильності сприйняття інформації та іiі інтерпретації за допомогою перепитування;

18) співпереживання. Уміння відчути емоційний стан учасника комунікації, допомогти співрозмовнику завдяки вербалізації ідентифікувати його й урахувати вищезазначене під час подальшої комунікації;

19) узагальнення. Узагальнити факти таким чином, щоб виникла підстава для продовження спілкування;

20) імпровізація. Уміння під час інтерв'ю не тільки поставити незаплановане запитання, доречність якого зумовлена відповідями інтерв'юйованого, а й, відчуваючи зміну емоційного фону інтерв'ю, завдяки незапланованим вербальним і невербальним засобам зробити його оптимальним для реалізації своєї стратегії. Вважаємо, що використання імпровізації під час інтерв'ю доречне лише за вищезгаданих обставин, перетворення інтерв’ю на суцільну імпровізацію свідчить про непрофесійність журналіста;

21) пряме ухилення від відповіді (констатація власної некомпетентності, відмова відповідати на запитання);

22) самовиправдання;

23) виправдання дій учасника комунікації, третіх осіб;

24) схвалення дій учасника комунікації третьою особою;

25) окреслення життєвих цінностей.

Комунікативні прийоми імпліцитної (позитивна, негативна, збалансована) маніпуляиії, диференціація якої відбувається залежно від мети прихованого впливу на учасника комунікації, про яку він не знає.

1. Цілеспрямоване часткове інформування, що призводить до унеможливлення об’ єктивного аналізу конкретної проблеми або ситуації та озвучення помилкових висновків.

2. Цілеспрямоване використання інформаційного шуму, що позбавляє інтерв'юйованого можливості зосередити увагу на головному через іiі розбалансування. 
3. Цілеспрямоване зміщення акцентів під час узагальнення інформації.

4. Цілеспрямоване формулювання неправильних висновків із метою емоційного розбалансування інтерв'юйованого та створення когнітивного дисонансу.

5. Прохання однозначно оцінити контраверсійні явище та ситуацію, які потребують детального аналізу й об'єктивної оцінки.

6. Прохання відповісти на запитання, що потребує розлогої відповіді, використовуючи лише стверджувальні або заперечувальні слова.

7. Використання контраверсійних вербальних та невербальних комунікативних засобів.

8. Підкреслення компетентності учасника комунікації за умови формулювання запитань, що не мають відношення до сфери його компетентності.

9. Цілеспрямоване використання безапеляційних i радикальних тверджень, що змушує учасника комунікації вступати в дискусію.

10. Формулювання запитань, спрямованих на моделювання позитивного образу учасника комунікації, третіх осіб тощо.

11. Формулювання запитань, спрямованих на моделювання негативного образу учасника комунікації.

12. Цілеспрямоване використання дифамаційної, неправдивої інформації про учасника комунікації для виникнення мотивації давати відповіді на запитання.

13. Цілеспрямоване використання неправильної або частково неправильної інтерпретації інформації, озвученої раніше учасником комунікації.

14. Використання повторного запитання, на яке учасник комунікації раніше відповідати не захотів.

15. Використання в запитанні лексем, лексичне значення яких учаснику комунікації не відоме.

16. Непряма конструктивна критика чужих моделей поведінки, завдяки якій учасник комунікації здогадується про свої недоліки.

17. Непряма деструктивна критика чужих моделей, завдяки якій учасник комунікації здогадується про свої недоліки.

18. Озвучення учасником комунікації (інтерв’юером) своєї точки зору (переважно контрарної позиції учасника комунікації - інтерв'юйованого).

19. Використання подвійних стандартів для оцінювання явища або ситуації.

20. Використання інформації, яка імпліцитно спонукає учасника комунікації до міркувань й оприявнення власної точки зору.

21. Непряме схвалення думок і вчинків учасника комунікації, третіх осіб.

22. Непряме уникання відповіді (відсилання до компетентних джерел інформації, констатація неможливості об'єктивно оцінити ситуацію, ігнорування запитання).

Декодування мовленнєвих прийомів експліцитної та імпліцитної маніпуляції може бути трансформованим унаслідок виникнення комунікативних бар'єрів, одним із яких є поява ілюзорної імпліцитної маніпуляції, зумовленої контраверсійністю реальних інтенцій одного учасника комунікації і їхнього декодування іншим учасником комунікації. Від цього залежатиме якість формування первинного тексту інтерв'ю.

3 огляду на вищевикладене запропоновані О. Кузьменко стратегії самопрезентації респондента й представлення респондента журналістом (Кузьменко, 2019), на нашу думку, повинні реалізовуватися завдяки тактиці взаємоманіпуляції, що передбачає використання 
вищезазначених комунікативних прийомів, завдяки яким відбувається моделювання образів інтерв'юера й інтерв'юйованого. Крім того, різний набір запитань, відповідей, а також активізація під час комунікації різних маніпулятивних комунікативних прийомів може сприяти моделюванню різних образів інтерв'юера й інтерв'юйованого. Їхнє формування відбувається з урахуванням багатьох інших чинників: епістемної детермінації світоглядів співавторів, жанру й жанрових модифікацій журналістського тексту, специфіки опрацювання фактичного матеріалу й особливостей його вербального, невербального втілення, відповідності тексту нормам чинного законодавства, особливостей сприйняття медіааудиторією журналістського тексту, її здатності помітити в тексті маркери світоглядної позиції інтерв'юера й інтерв'юйованого, особливості їхнього інтелекту та внутрішнього світу, репрезентовані за допомогою різноманітних засобів.

Змодельовані спочатку образи інтерв'юера та інтерв'юйованого можуть трансформуватися під час обробки журналістського матеріалу редактором та художнім редактором. Ступінь вищезгаданої трансформації залежить від міри втручання в текст, а також узгодження зроблених правок i відповідності відредагованого й оформленого матеріалу задуму авторів. Як правило, ступінь трансформації первинного журналістського тексту залишається за “кадром”. Є випадки, коли втручання в текст і його оформлення стає результатом або одноосібного рішення редактора та художнього редактора, або наполегливих "рекомендацій” вищезазначених фахівців, під впливом яких авторам доводиться погодитися із трансформаціями тексту. Не варто забувати й про юридичний аспект підготовки журналістського матеріалу до друку, оскільки в деяких редакціях $\epsilon$ медіаюрист, який повинен проаналізувати запропонований текст щодо дотримання норм чинного законодавства, звернувши увагу на коректність висловлювань, відсутність дискримінаційної складової тощо.

3 огляду на вищевикладене інтерв'ю може бути результатом колективної праці або інформаційним продуктом журналіста за умови виконання ним функцій усіх вищезазначених фахівців (редактора, коректора, художнього редактора, юриста). Крім цього, треба пам'ятати, що під час інтерв'ю у створенні тексту беруть участь автори: інтерв'юер та інтерв'юйований, які в процесі узгодження інтерв'ю можуть вносити в нього суттєві зміни, що трансформують образи інтерв'юера й інтерв'юйованого. Подальша трансформація вищезазначених образів відбувається під час сприйняття журналістського тексту медіаудиторією, представники якої продукують мультиваріантні образи авторів інтерв'ю. Необхідно врахувати, що для моделювання образу інтерв'юера й інтерв'юйованого важливим чинником $\epsilon$ те, чи $\epsilon$ реципієнт представником тієї ж епістеми, у межах якої було створено журналістський текст. Якщо вищезгадана синхронія відсутня, то може виникнути когнітивний дисонанс, який вплине на моделювання образів інтерв'юера й інтерв'юйованого. Наприклад, на нашу думку, образ актора Андрія Харитонова (Харитонов, 1995), творча активність якого була загальмована кризою 90-х років XX століття, може мати різні варіанти моделювання представниками різних епістем (реципієнта, який знає про 90-ті роки XX століття лише 3 уроків історії; реципієнт, який виживав під час вищезазначеної кризи): цинічної, меркантильної, безпринципної людини, яка намагається заробляти гроші різними способами (екскортпослуги за кордоном, робота на політичні партії без конкретних політичних переконань); відвертої людини, яка правдиво відповідає на провокативні запитання інтерв'юера й розкриває нюанси непростого життя актора в часи фінансових труднощів. 
На нашу думку, саме запитання інтерв'юера, орієнтовані на досягнення мети, поставленої інтерв'юером, відсутність комунікативних бар'єрів, що дозволяє максимально розкритися інтерв'юйованому, свідчать про професіоналізм інтерв'юера i $\epsilon$ засобом моделювання його образу. На жаль, інтерв'юер не завжди вербалізує мету інтерв'ю, що створює додаткові труднощі під час оцінювання професіоналізму журналіста й доречності поставлених запитань, класифікацію яких запропонувала Марія Лукіна (Лукина, 2003) у своєму посібнику. На нашу думку, основними критеріями якісно сформульованого запитання $\epsilon$ актуальність, новизна, оригінальність, позитивна комунікативна реакція інтерв'юйованого на поставлене запитання.

В інтерв'ю не тільки запитання, а й іноді вступні і заключні частини інтерв'ю, констатація деяких фактів, ремарки можуть містити такі форми вияву образу інтерв'юера:

1) автобіографізм (спогади про випадки зі свого життя);

2) вербалізацію своїх емоцій;

3) вияв емоцій за допомогою невербальних засобів спілкування, зафіксованих у ремарках;

4) прогнозування розгортання подій щодо себе (інтерв’юера);

5) вербалізацію своєї оцінки;

6) міркування;

7) припущення;

8) розповідь про створення або виникнення комунікативної ситуації, учасником якої він $€$;

9) розповідь про бекграунд попередніх спілкувань з інтерв’юйованим;

10) вербалізацію вражень від комунікації;

11) побажання інтерв'юйованому;

12) самохарактеристику.

Усі вищезазначені форми активної авторизації інтерв'юера, містячи вербальні маркери світоглядної позиції, інтелектуального, внутрішнього світу й інформацію про стать, вік, соціальний статус інтерв'юера, а також невербальні засоби спілкування, зазначені в ремарках, є безпосередніми засобами моделювання образу інтерв'юера.

На нашу думку, тематичні вузли інтерв'ю, його проблематика, презентація інтерв'юйованого, використання цитат, алюзій, ремінісценцій, а також згадка про третіх осіб $\epsilon$ опосередкованою характеристикою інтерв'юера. Паралінгвістичні засоби, зокрема шрифт, колір, курсив, фотографії тощо, на нашу думку, теж опосередковано характеризують образ інтерв’юера. Необхідно відзначити, що взаємодія тексту й фотографії сприяє виникненню додаткових смислів, що відповідають інтенціям інтерв'юера, який разом із художнім редактором бере активну участь у їхьому художньому оформленні на газетній площині. Якщо журналіст не контролює процес художнього оформлення свого інформаційного продукту, під час роботи художнього редактора 3 текстом та фотографіями можуть виникнути додаткові смисли, що не відповідають або частково відповідають інтенціям журналіста. Крім того, у процесі сприйняття всього інформаційного продукту (тексту й фотографій) медіаудиторія залежно від багатьох факторів може повністю, частково декодувати закладені в ньому смисли або продукувати консонансні або дисонансні смисли, які не мають відношення до інтенцій журналіста. Крім вищезазначеного, ще одним засобом опосередкованої характеристики інтерв'юера, на нашу думку, є заголовок інтерв'ю, а також композиція тексту. 
Отже, до безпосередніх засобів моделювання образу інтерв’юера, на нашу думку, належать формулювання запитань, форми вияву авторського “я", маніпулятивні комунікативні прийоми, вербальні засоби презентації світоглядної позиції, епістемної характеристики, використання невербальних засобів, їхня консонастність чи дисонансність щодо вербальних засобів, до опосередкованих - паралінгвістичні засоби оформлення інтерв'ю, його композиція, заголовок, характеристика інтерв'юйованого, третіх осіб, ситуації, явища, характеристика інтерв'юера інтерв'юйованим, використання цитат, ремінісценцій, алюзій, тематичні вузли й проблематика інтерв'ю.

На нашу думку, безпосередні засоби моделювання образу інтерв'юйованого - це

1) автобіографізм (спогад про випадки зі свого життя);

2) вербалізація своїх емоцій;

3) вияв емоцій за допомогою невербальних засобів спілкування;

4) прогнозування розгортання подій щодо себе (інтерв'юйованого);

5) вербалізація своєї оцінки;

6) міркування;

7) припущення;

8) розповідь про бекграунд попередніх спілкувань з інтерв'юером або третіми особами;

9) вербалізація вражень від комунікації;

10) побажання інтерв'юеру, третім особам, медіаудиторії;

11) самохарактеристика;

12) маніпулятивні мовленнєві прийоми;

13) вербальні засоби презентації світогляду, епістемної характеристики;

14) використання невербальних засобів, їхня консонансність чи дисонансність щодо вербальних засобів.

До опосередкованих засобів моделювання - характеристика інтерв'юйованого iнтерв'юером, характеристика інтерв'юйованим третіх осіб, ситуації, явища; заголовок, паралінгвістичні засоби оформлення інтерв'ю за умови узгодження нюансів художнього оформлення інтерв'ю; використання цитат, ремінісценцій, алюзій, спогадів про випадки із життя третіх осіб.

Вважаємо, що журналістські тексти, домінантною частиною яких є інтерв’ю, створені в 90-ті роки XX століття, дають можливість активізувати ширший діапазон засобів моделювання інтерв'юера й інтерв'юйованого. Якщо вищезгаданому журналістському текстові притаманна поліавторність (журналіст, який написав мінінарис, творчу біографію тощо, інтерв'юер, інтерв'юйований), вона дозволяє вербалізувати різні точки зору авторів (журналіст, інтерв'юер) на інтерв'юйованого, які навіть можуть бути представниками різного ментального й культурного простору.

\section{Висновки}

1. Образи інтерв'юера й інтерв'юйованого проходять такі етапи моделювання: формування вищезазначених образів під час комунікативного процесу, трансформація образів інтерв'юера й інтерв'юйованого під час роботи над журналістським текстом, моделювання у свідомості реципієнта образів інтерв'юера й інтерв'юйованого, детермінованих специфікою сприйняття й інтерпретації запропонованої інформації представником медіааудиторії. 
2. Образам інтерв’юера й інтерв'юйованого притаманна мультиваріативність. Чинниками мультиваріації є мета інтерв'ю, комунікативна ситуація, учасники комунікації, їхні світоглядні орієнтири, дискурс, епістемна характеристика учасників комунікації, трансформація образів, зумовлена робочим процесом і специфікою сприйняття, інтерпретації інформації медіааудиторією, тощо.

3. Є безпосередні та опосередковані засоби моделювання образу інтерв’юера й інтерв'юйованого, активізація більшості яких відбувається під час утворення комунікативного маніпулятивного кола.

4. Під час моделювання образів інтерв'юера й інтерв'юйованого треба враховувати епістемну характеристику (епістемно-новаційний, епістемно-консервативний, епістемноадаптивний) учасників тріади “інтерв’юер - інтерв’юйований - медіаудиторія”.

\section{Література}

Бацевич, Ф.С (2004). Основи комунікативної лінгвістики. Київ: Академія, 342.

Большой психологический словарь (2009). - 4-е изд., расширенное / Сост. и общ. ред. Б.Г. Мещеряков, В.П. Зинченко. - М.:АСТ: АСТ МОСКВА; СПб.: Прайм-Еврознак, 811.

Быкова, Ю.Н. (2009). Образ журналиста: эволюция восприятия в новейшее время. Вестник Челябинского государственного университета, № 7 (188), 4-7.

Вестник Челябинского государственного университета. №7 (188). Филология. Искусствоведение. Вып. 41, 5-7.

Долгина, Е.С., Веснина, М.А. (2015). Интервью: понятие, цель, задачи, функции. Молодой учёный. № 7 (87) апрель, 1109-1111.

Эпистема http://pmatsuk.narod.ru/epistema.html

Кузьменко, О.Ю. (2015). Особливості комунікативної ситуації інтерв'ю та їі складників. Science and Education a New Dimension. Philology, III (9), Issue: 44, 58-61.

Кузьменко, О.Ю. (2019). Презентація респондента в анлійськомовному інтерв'ю масмедійного дискурсу: лінгвокомунікативний $i$ лінгвокогнітивний виміри. [Неопублікована кандидатська дисертація]. Херсон, 256.

Лукина, М. М. (2003). Технология интервью. Москва : Аспект Пресс, 191.

Распопова, С.С. (2015). Автор как реальный человек и образ автора в медиатексте. Boпросы теории и практики журналистики. Т. 4. №2, 149-158.

Сазонова, Ю. О. (2013). Внутрішньожанрові типи інтерв’ю в спортивній клубній пресі (на прикладі журналу “Шахтёр”). Держава та регіони. Серія Соціальні комунікації. №2 (14), 106-111.

Сербин, С. (2015). Рольові функції маніпулятора в прямоефірних інтерв'ю. Medianростір. Вип. 7, 32-41.

Урунова, Р.Д. (2015). О способах авторизации современного газетного текста. Вектор науки. ТГУ. № 3-2 (33-2), 263-266.

Френкель, О. (2014). Жанрова своєрідність інтерв’ю як типу комунікації: портретне інтерв’ю. Єдність навчання $і$ наукових досліджень - головний принцип університету. Київ : Видво НПУ імені М. П. Драгоманова, 30-31.

Харитонов, А. (1995). Андрей Харитонов: “Мы, артисты, - уроды...”. Кінокур’єр. №21 (57), 8.

Что такое эпистема? (http://pmatsuk.narod.ru/epistema.html). 
Шарапов, Э. Х. (2017). Жанр интервью: видовая составляющая. Филология. Молодой учёный. №12 (146) март, 668-670.

Штирьова, С. В. (2006). Прагмалингвистическая характеристика интервью:на материале франиузской прессы [Неопубликованная кандидатская диссертация]. Москва, 163.

Kazimova, J. (2018). To the Concept of the Format of the Genreof Interviews in Journalism. Bulletin of Lviv Polytechnic National University. Series: Journalistic sciences, Vol. 896, Number 2 : 65-69 https://doi.org/10.23939/sjs2018.01.065

Kovtunenko, I., Bylkova, S., Borisenko, V., Minakova, N., \& Rogacheva, V. (2018). Interview as a genre of new media communication: Rhetorical relations and pragmatic effects, Linguae, January X, 11(2):95-105 DOI:10.18355/XL.2018.11.02.08 https://www.researchgate. net/publication/325210347_Interview_as_a_genre_of_new_media_communication_Rhetorica 1 relations_and_pragmatic_effects

Melo, J. M. de, Assis, F. de (2016). Journalistic Genres and Formats: a Classification Model. Intercom - RBCC, São Paulo, Vol. 39, n.1, 39-54. DOI: 10.1590/1809-5844201613

Natsvlishvili, P. (2013). For the Genesis of Interview as a Genre. European Scientific Journal December (Special), Vol. 2, 384-387.

\section{Reference}

Batsevych, F.S (2004). Osnovy komunikatyvnoi linhvistyky [Fundamentals of communicative linguistics]. Kyiv : Akademiia, 342.

Meshcheryakov, B.G. and Zinchenko, V.P. [ed.]. (2009). Bolshoj psihologicheskij slovar [Large psychological dictionary]. Moscow : AST: AST MOSKVA; St. Petersburg : Prajm-Evroznak, 811.

Bykova, Yu.N. (2009). Obraz zhurnalista: evolyuciya vospriyatiya v novejshee vremya [The image of a journalist: the evolution of perception in modern times]. Vestnik Chelyabinskogo gosudarstvennogo universiteta - Bulletin of the Chelyabinsk State University, № 7 (188), 4-7.

Vestnik Chelyabinskogo gosudarstvennogo universiteta. Filologiya. Iskusstvovedenie [Bulletin of the Chelyabinsk State University. Philology. Art criticism] (2009). №7 (188), Vyp. 41, 5-7.

Dolgina, E.S., Vesnina, M.A. (2015). Intervyu: ponyatie, cel, zadachi, funkcii [Interview: concept, purpose, objectives, functions]. Molodoj uchyonyj -Young scientist, № 7 (87) Aprel, 11091111.

Epistema (2021). http://pmatsuk.narod.ru/epistema.html

Kuzmenko, O.I. (2015). Osoblyvosti komunikatyvnoi sytuatsii interviu ta yii skladnykiv [Features of the communicative situation of the interview and its components]. Science and Education a New Dimension. Philology, III (9), Issue: 44, 58-61.

Kuzmenko, O.I. (2019). Prezentatsiia respondenta $v$ anliiskomovnomu interviu masmediinoho dyskursu: linhvokomunikatyvnyi i linhvokohnityvnyi vymiry [Respondent's presentation in an English-language interview of mass media discourse: linguocommunicative and linguocognitive dimensions] [Unpublished $\mathrm{PhD}$ thesis]. Kherson, 256.

Lukyna, M.M. (2003). Tekhnolohyia interviu [Interview technology]. Moscow : Aspekt Press, 191.

Raspopova, S.S. (2015). Avtor kak realnyj chelovek i obraz avtora v mediatekste [The author as a real person and the image of the author in the media text]. Voprosy teorii i praktiki zhurnalistiki-Questions of theory and practice of journalism, T. 4, №2, 149-158.

Sazonova, Yu. O. (2013). Vnutrishnozhanrovi typy interviu v sportyvnii klubnii presi (na prykladi zhurnalu "Shakhtor") [Intra-genre types of interviews in the sports club press (for example, 
Shakhtar magazine)]. Derzhava ta rehiony. Seriia Sotsialni komunikatsii - State and regions. Social Communications Series, №2 (14), 106-111.

Serbyn, S. (2015). Rolovi funktsii manipuliatora v priamoefirnykh interviu [Manipulator role roles in live interviews]. Mediaprostir - Media space, Vyp. 7, 32-41.

Urunova, R.D. (2015). O sposobah avtorizacii sovremennogo gazetnogo teksta [About authorization methods for modern newspaper text]. Vektor nauki - Science vector. TGU. № 3-2 (33-2), 263-266.

Frenkel, O. (2014). Zhanrova svoieridnist interviu yak typu komunikatsii: portretne interviu [Genre originality of interview as a type of communication: portrait interview]. Yednist navchannia $i$ naukovykh doslidzhen - holovnyi pryntsyp universytetu - The unity of teaching and research is the main principle of the university. Kyiv : Vyd-vo NPU imeni M. P. Drahomanova, 30-31.

Haritonov, A. (1995). Andrej Haritonov: "My, artisty, - urody..." [Andrey Kharitonov: "We, artists, are freaks ..."]. Kinokurijer - Film courier. №21 (57), 8.

Chto takoe epistema? [What is an episteme?] (http://pmatsuk.narod.ru/epistema.html).

Sharapov, E. H. (2017). Zhanr intervyu: vidovaya sostavlyayushchaya [Interview genre: species component]. Filologiya. Molodoj uchyonyj - Philology. Young scientist. №12 (146) Mart, $668-670$.

Kazimova, J. (2018). To the Concept of the Format of the Genreof Interviews in Journalism. Bulletin of Lviv Polytechnic National University. Series: Journalistic sciences, Vol. 896, Number 2 : 65-69 https://doi.org/10.23939/sjs2018.01.065

Kovtunenko, I., Bylkova, S., Borisenko, V., Minakova, N., \& Rogacheva, V. (2018). Interview as a genre of new media communication: Rhetorical relations and pragmatic effects, Linguae, January X, 11(2):95-105 DOI:10.18355/XL.2018.11.02.08 https://www.researchgate. net/publication/325210347_Interview_as_a_genre_of_new_media_communication_Rhetorica 1_relations_and_pragmatic_effects

Melo, J. M. de, Assis, F. de (2016). Journalistic Genres and Formats: a Classification Model. Intercom - RBCC, São Paulo, Vol. 39, n.1, 39-54. DOI: 10.1590/1809-5844201613

Natsvlishvili, P. (2013). For the Genesis of Interview as a Genre. European Scientific Journal December (Special), Vol. 2, 384-387.

\title{
ОСОБЛИВОСТІ МОДЕЛЮВАННЯ ОБРАЗІВ ІНТЕРВ'ЮЕРА Й ІНТЕРВ'ЮЙОВАНОГО В ДРУКОВАНИХ ЗМІ
}

\author{
Ганна Холод, \\ кандидат філологічних наук, \\ директор ГО \\ "Науково-освітній иеентр "УСПІШНИЙ" \\ (м. Київ, Украӥна)
}

\section{Анотація}

Метою дослідження в статті було обрано з'ясування особливостей моделювання образів інтерв'юера й інтерв'юйованого в друкованих ЗМІ. Дослідження дозволило розширити теоретичну базу щзодо інтерв'ю, заповнивщи деякі прогалини й окресливщи 
дискусійні моменти. Запропоновано власне бачення щзодо специфіки моделювання образів інтерв'юера й інтерв'юйованого в друкованих ЗМІ. Презентовано трьохетапний механізм моделювання образів інтерв'юера й інтерв'юйованого. Окреслено специифіку виникнення й функиіонування комунікативного маніпулятивного поля між учасниками комунікації. Сформульовано перелік комунікативних маніпулятивних прийомів, щцо можуть активізуватися під час появи маніпулятивного поля.

Було використано методи опису, аналізу, синтезу й узагальнення. Методикою стала така дослідницька процедура: 1) серед теоретичного матеріалу обрано наукові роботи, дотичні до обраної нами теми; 2) проаналізовано наукові статті, монографії; 3) виокремлено в них дискусійні твердження й викладено свою точку зору щэодо предмета дослідження; 4) запропоновано свою концепџію моделювання образу інтерв'юера й інтерв'юйованого.

Результати й обговорення дали можливість сформулювати висновки. По-перше, образи інтерв'юера й інтерв'юйованого проходять такі етапи моделювання: формування вищезазначених образів під час комунікативного прочесу, трансформачія образів інтерв'юера ц̆ інтерв'юйованого під час роботи над журналістським текстом, моделювання у свідомості реципієнта образів інтерв'юера й інтерв'юйованого, детермінованих специифікою сприйняття й інтерпретації запропонованої інформації представником медіааудиторії. По-друге, образам інтерв'юера й інтерв'юйованого притаманна мультиваріативність. Чинниками мультиваріації $\epsilon$ мета інтерв'ю, комунікативна ситуація, учасники комунікаиї, їхні світоглядні орієнтири, дискурс, епістемна характеристика учасників комунікачіï, трансформачія образів, зумовлена робочим прочесом і специифікою сприйняття, інтерпретації інформації медіааудиторією, тощчо.

Ключові слова: інтерв'юйований, інтерв'юер, медіааудиторія, моделювання.

Submitted to the editor -14.03 .2021$

Reviewed-26.05.2021

Accepted for printing - 10.07.2021

Подано до редакиії-14.03.2021

Рецензовано - 26.05.2021

Прийнято до друку - 10.07.2021 